\title{
Raimon Panikkar, Emanuel Severino, Parliamo della stessa retaltà? Per un dialogo tra Oriente e Occidente, Wydawnictwo Jaca Book, Mediolan 2014, ss. 78.
}

Są takie książki, których objętość jest odwrotnie proporcjonalna do wagi treści w nich poruszanych. Niekiedy jedno zdanie wypowiedziane, czy te $\dot{z}$ napisane, może stać się przedmiotem wielowiekowej dyskusji, tematem licznych opracowań i rozpraw naukowych. Wystarczy choćby wspomnieć wersety z Parmenidesa lub kilka zdań z Proslogoinu św. Anzelma z Canterbury. Z podobną sytuacją, oczywiście toutes proportions gardées, spotyka się czytelnik 78 stronicowej książki pt. Parliamo della stessa realtà? Per un dialogo tra Oriente e Occidente (Czy mówimy o tej samej rzeczywistosci? O dialog pomiędzy Wschodem i Zachodem) wydanej w 2014 roku przez mediolańskie wydawnictwo "Jaca Book”. Jest to zapis dyskusji dwóch, w Polsce stosunkowo mało znanych autorów - Emanuela Severino i Raimona Panikkara. Spotkanie odbyło się 9 marca 2004 roku w Aula Magna Instytutu Architektury Uniwersytetu w Wenecji. Dużą część publikacji stanowi posłowie profesora filozofii Uniwersytetu Weneckiego Luigi Vero Tarca, który był moderatorem dyskusji.

Emanuel Severino jest znany w Polsce głównie jako badacz Parmenidesa (Emanuele Severino, Powrót do Parmenidesa, pod red. Seweryna Blandziego. Wydawnictwo IFiS PAN, Warszawa 2005) oraz jako ten, który w 2006 roku na łamach włoskiego dziennika Corriere della Sera zaproponował papieżowi Benedyktowi XVI debatę na temat rozumienia relatywizmu. W latach 19541969 Severino wykładał filozofię na Katolickim Uniwersytecie Najświętszego Serca w Mediolanie. Jego publikacje wywoływały żywą dyskusję na forum uniwersytetu oraz w Kongregacji Nauki Wiary. W 1969 roku po wnikliwych analizach i opinii Cornelia Fabro Kościół oficjalnie ogłosił sprzeczność pomiędzy nauczaniem Severino i Kościoła. 
Raimon Panikkar, może nieco lepiej znany polskiemu czytelnikowi, to również postać skomplikowana zarówno z punktu widzenia biograficznego, jak i stylu uprawiania filozofii. Urodzony w Hiszpanii, wychowany w dwóch religiach i kulturach, związany z Opus Dei, ksiądz katolicki od 1946 roku. Poszukiwacz śladów Chrystusa w hinduizmie. Dla wyrażenia swojej całościowej wizji rzeczywistości ukuł nowe pojęcie „kosmoteandryzm” mające oddać współprzenikanie Boga, człowieka i kosmosu. W podeszłym wieku ożenił się i adoptował dziecko, określając siebie samego jako „kapłana religii kosmicznej według obrządku Melchizedeka”. Zarówno jego myśl, jak i życie obfitowały w paradoksy.

Już na samym początku czytelnik, znając rys biograficzny i zarys myśli dyskutantów, może mieć wątpliwości, czy na pewno są oni reprezentatywni dla zaznaczonych w tytule dwóch obszarów kulturowych: Wschodu i Zachodu. Całościowa lektura książki także nie pozwala pozbyć się wątpliwości w tej kwestii. Symptomatyczne jest także to, że linia podziału pomiędzy Wschodem i Zachodem przebiega przez koncepcję bytu oraz jego poznania.

Punktem wyjścia dla rozmowy była próba definicji całościowej wizji rzeczywistości. Prof. Severino stwierdza, iż cała zachodnia kultura zbudowana jest na dążeniu człowieka do stawania się „innym”. Stanowi to swego rodzaju „preontologiczne” pragnienie człowieka, które wyrażają także biblijne opowiadanie o kuszeniu pierwszych rodziców i obietnica złego ducha: „będziecie jako bogowie”. To „szaleństwo” stawania się, jak ujmuje to sam Severino, jest obecne także w chrześcijaństwie, czego koronnym dowodem ma być pojęcie Pokarmu eucharystycznego: chrześcijanie, według włoskiego filozofa, spożywają Ciało Boga, aby stawać się „innymi”, Bogiem. „W końcu stawaniem się innym jest śmierć i ostatecznie anihilacja śmierci. Każde usiłowanie ucieczki przed tą udręką, polegające na wzywaniu niezmiennego Boga wewnątrz absolutnej prawdy, skazane jest na porażkę" (s. 18). Problem stawania sie jest dla Severino zasadniczy: szaleństwo stawania się przeciwstawia Severino pojęciu bytu, tak jak rozumiał go Parmenides, do którego myśli (źródłowo, nieprzetworzonej przez Platona) proponuje powrócić. Jego zdaniem, antyczna Grecja popełniła błąd, który powtarza się w dziejach całej zachodniej filozofii, a który lapidarnie można ująć tak: byt pochodzi z nicości, czasowo jest mu udzielana 
egzystencja i sukcesywnie wraca do nicości. Dla włoskiego filozofa opozycja pomiędzy bytem i nie-bytem jest absolutna - byty nie wyłaniają się z nie-bytu i do żadnego nie-bytu nie powracają. Według Severino szczyt wiary w zmianę i stawanie się stanowi współczesna technika, która tworzy przekonanie, że ludzkie działanie może zmieniać rzeczywistość w coś innego.

Te dwa pojęcia nie mają ze sobą nic wspólnego - byt nie przechodzi w nicość, gdyż byt jest wieczny, a to, co widzimy, jest jego obecnością na tzw. kręgu pojawiania się (cerchio dell'apparire). Następstwem takiego postawienia sprawy jest przeformułowanie przez Severino zasady niesprzeczności, gdyż ta zaproponowana przez Arystotelesa, głosząca, iż „niepodobna, ażeby coś zarazem było i nie było" dopuszcza moment, w którym może coś nie-być.

Prawda bytu, według Panikkara, przekracza ludzkie poznanie i to jest punkt sporny hinduskiego myśliciela z całą tradycją parmenidejską utożsamiającą byt z myślą. W tym kontekście staje się bardziej zrozumiała interpretacja Panikkara zasady niesprzeczności, która, według niego, jest co najwyżej regula falsi, nie zaś regula veri. Cały wysiłek Panikkara w dialogu $\mathrm{z}$ Severino nakierowany jest na odrzucenie racjonalizmu in sesno stretto i zwrócenie się w kierunku doświadczenia mistycznego, które autor rozumie jako przejaw racjonalności, lecz in senso lato. Dialog Severino i Panikkara w ostatecznym rozrachunku oscyluje wokół dawnego problemu bytu i jego poznania, dotykając tym samym spraw fundamentalnych. Rozmówcy posługują się dla ujęcia tego zagadnienia obrazem morza i sieci. Morze jest alegorią rzeczywistości, sieci zaś siłami ludzkiego poznania. Dla Panikkara problemem jest rzeczywistość, która wymyka się racjonalnym ujęciom i logice dwuwartościowej. Racjonalizm i cała Zachodnia tradycja w rozumieniu Panikkara jest jedynie małą wysepką dryfującą po oceanach rzeczywistości niedającej się zamknąć w sztywnym gorsecie logiki dwuwartościowej.

Niewątpliwie ten krótki tekst ma w sobie dużą siłę inspirującą do przemyśleń i to na tematy najistotniejsze dla filozofii - bytu i poznania. Tym jednak, co nie daje spokoju, to nieustannie towarzyszące uczucie, że dialog ten był prowadzony na dwóch różnych poziomach - zawodowego filozofa oraz myśliciela-mistyka. Oczywiście powyższa uwaga nie wynika z przekonania, iż takie dialogi nie są możliwe lub bezowocne, lecz sugeruje, że wiele kontrowersji pomiędzy interlokutorami wynika właśnie z tej różnicy, a nie z rzeczywistego 
innego rozumienia zagadnienia. Trzeba uczciwie przyznać, że obydwie wizje mają coś z mistycznego podejścia do rzeczywistości. W przypadku Panikkara to stwierdzenie nie wymaga dłuższych uzasadnień. Nieco inaczej ma się sprawa z Severino oraz jego programem powrotu do Parmenidesa jako antidotum na nihilizm obecnego czasu. Włoski filozof próbuje w ten sposób poszukiwać głębi rzeczywistości, dokonuje swego rodzaju parareligijnej sakralizacji rzeczywistości. W ten sposób neoparmenideizm, jak sam Severino określa swój nurt myślenia, jest formą świeckiej mistyki, głębi bez Boga lub swoistej mistyki postmodernizmu.

Podczas lektury tekstu daje się zauważyć pewną przewagę Panikkara w prezentowanej dyskusji. Jest to, być może, konsekwencją jego historii życia i formacji intelektualnej, dzięki której nauczył się dobrze wyrażać koncepcje Wschodu aparatem pojęciowym Zachodu. Dlatego w dyskusji z Severino to on staje się tym, który jest „ponad”, jest punktem odniesienia, nie tylko ze względu na to, iż jego koncepcja jest bardziej pojemna (a to z powodu interpretacji zasady niesprzeczności), ale również przez wyżej wspomniany fakt wielokulturowej formacji intelektualnej i duchowej.

Istnieje jeszcze inny wymiar tego dialogu, który jest bardzo cenny dla każdego i w każdej debacie - szacunek dla rozmówcy. Panikkar, rozpoczynając dyskusję z Severino, wypowiada słowa, które winny się stać mottem dla każdego, kto zabiera głos w jakiejkolwiek dyskusji: „krytyka Severino wydaje mi się bardzo słuszna, mimo że błądząca!, lecz bardzo słuszna. Nie robię sobie żartów. Mówię stuszna, ponieważ podaje przyczyny swojej głębokiej krytyki: dotyka rzeczywiście fundamentów i jego głos musi być wysłuchany” (s. 22).

Niezależnie od tego, czy zgadzamy się z tezami rozmówców oraz sposobem argumentacji, czy też nie, dwie przyczyny sprawiają, że warto zapoznać się z 78 stronicami omawianej publikacji: waga tematu oraz kultura dialogu.

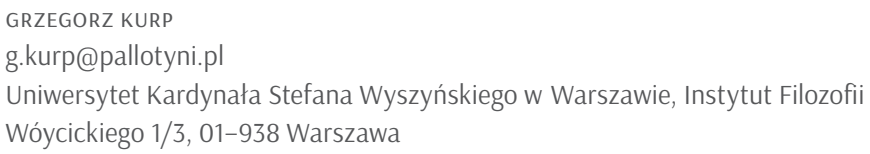

